\title{
Deep Venous Thrombosis in Children with Musculoskeletal Infection
}

\author{
Lawson A. B. Copley and Ngozi Okoro \\ Orthpaedic Surgery, University of Texas Southwestern \\ USA
}

\section{Introduction}

Deep venous thrombosis (DVT) is rarely identified in children. However, there has been an increase in the reported association of DVT with pediatric musculoskeletal infection. ${ }^{1-13}$ The relationship appears to be tied to the rise of community-acquired, Methicillin-resistant Staphylococcus aureus (CA-MRSA). ${ }^{5-13}$ Children who are affected by musculoskeletal infection and deep venous thrombosis appear to share similar clinical features. They often require intensive care, surgical intervention, and prolonged hospitalization.5,6,9 Pulmonary involvement, including pneumonia and septic pulmonary emboli, is frequent.9,11 It is possible that the causative organisms have an underlying genetic makeup, such as Panton Valentine leukocidin, that potentiates the cascade of clinical features seen in these children. $6,8,10$ This chapter explores the relationship of DVT and pediatric musculoskeletal infection through meta-analysis of the medical literature from the past forty years. To the extent possible, risk factors and clinical characteristics are evaluated and evaluation and treatment strategies are discussed.

\section{Review of literature}

The earliest case report of DVT associated with osteomyelitis was by Horvath et al. in 1971.14 Including that original case, 58 cases of pediatric DVT associated with musculoskeletal infection have surfaced in the medical literature (see table 1). ${ }^{1-19}$ A decade by decade review of the case occurrence reveals an exponential increase in the number of cases reported since 2000, during which time 51 new cases have been identified. This is compared to one case from the 1970s and 3 cases from each decade of the 1980s and 1990s. The largest series, to the present, was reported at a single institution, Children's Medical Center of Dallas, compiled from two separate reports with overlapping study periods and included 15 unique cases of children with DVT.5,9 Of the four studies that report the incidence of DVT within a series of children with musculoskeletal infection, the total number of children with DVT is 32 among a total of 430 children reviewed giving an estimated incidence of DVT associated with musculoskeletal infection of $7.4 \% .3,6,8,9$

\section{Gender, age, type, and site of infection}

Several trends can be derived from the reported cases in a descriptive manner. Children with DVT were noted to be male 34 times out of the 46 cases in which gender was identified 


\begin{tabular}{|c|c|c|c|c|c|c|c|c|c|c|c|}
\hline Source & Year & Series & DVT & Age (y) & Sex & Type & Location & Organism & DVT Site & $\begin{array}{l}\text { Pulmonary } \\
\text { Findings }\end{array}$ & Features \\
\hline$\overline{\text { Horvath }^{14}}$ & 1971 & & 1 & 9 & $\bar{m}$ & Osteo. & $\begin{array}{l}\text { R proximal } \\
\text { tibia }\end{array}$ & MSSA & R femoral; popliteal & $\begin{array}{l}\text { L lower lobe } \\
\text { infiltrate }\end{array}$ & \\
\hline \multirow[t]{2}{*}{ Jupiter ${ }^{15}$} & 1982 & & 2 & 12 & $\mathrm{~m}$ & Osteo. & L humerus & MSSA & L arm deep & $\begin{array}{l}\text { Multiple } \\
\text { infiltrates }\end{array}$ & \\
\hline & & & & 12 & $\mathrm{f}$ & Osteo. & $\begin{array}{l}\text { L femur, } \\
\text { R tibia }\end{array}$ & MSSA & L femoral; popliteal & Diffuse infiltrates & \\
\hline Muhlendahl16 & 1988 & & 1 & 12 & $\mathrm{f}$ & Osteo. & $\begin{array}{l}\text { R distal } \\
\text { femur }\end{array}$ & MSSA & $\mathrm{R}$ femoral & $\begin{array}{l}\text { Multiple lung } \\
\text { emboli }\end{array}$ & \\
\hline \multirow[t]{2}{*}{ Smith $^{17}$} & 1997 & & 2 & 4 & $\mathrm{f}$ & Osteo. & L femur & $\mathrm{S}$ aureus & IVC and femoral & Pneumatoceles & Death \\
\hline & & & & 2.5 & $\mathrm{f}$ & Osteo. & L ilium & S aureus & IVC and common iliac & Pneumonia & \\
\hline Letts $^{18}$ & 1999 & & 1 & 11.5 & $\mathrm{~m}$ & Osteo. & Sacrum & MSSA & $\begin{array}{l}\mathrm{R} \text { popliteal; } \mathrm{R} \text { femoral; } \\
\mathrm{R} \text { atrium }\end{array}$ & $\mathrm{R}$ middle lobe SPE & \\
\hline \multirow[t]{3}{*}{ Gorenstein $^{19}$} & 2000 & & 3 & 11 & $\mathrm{~m}$ & Osteo. & $\begin{array}{l}\text { L proximal } \\
\text { femur }\end{array}$ & MSSA & L femoral & Pneumatoceles & Death \\
\hline & & & & 10 & $\mathrm{~m}$ & Osteo. & $\begin{array}{l}\text { L femoral } \\
\text { head }\end{array}$ & MSSA & L femoral & $\begin{array}{l}\text { Pneumonia, } \\
\text { empyema }\end{array}$ & Pneumot. \\
\hline & & & & 10 & $\mathrm{~m}$ & Osteo. & $\begin{array}{l}\text { L femoral } \\
\text { neck }\end{array}$ & S aureus & L iliac & $\begin{array}{l}\text { Multiple } \\
\text { infiltrates }\end{array}$ & \\
\hline \multirow[t]{4}{*}{ Walsh $^{2}$} & 2002 & & 4 & 11 & $\mathrm{~m}$ & Osteo. & $\begin{array}{l}\text { L distal } \\
\text { fibula }\end{array}$ & MSSA & L femoral; popliteal & $\begin{array}{l}\text { Bil. patchy } \\
\text { infiltrates }\end{array}$ & ICU \\
\hline & & & & 4 & $\mathrm{f}$ & Osteo. & $\begin{array}{l}\text { L femur, } \\
\text { R tibia }\end{array}$ & S aureus & $\begin{array}{l}\text { IVC; L common } \\
\text { femoral }\end{array}$ & patchy infiltrates & Death \\
\hline & & & & 2.5 & $\mathrm{f}$ & Osteo. & L ilium & S aureus & IVC; common iliac & Pneumonia & ICU \\
\hline & & & & 6 & $\mathrm{f}$ & Pyom. & L soleus & GABHS & L popliteal; peroneal & Unknown & Comp. sy. \\
\hline Newgard $^{1}$ & 2002 & & 1 & 12 & $\mathrm{~m}$ & Osteo. & Sacroiliac & MSSA & $\mathrm{R}$ common iliac & SPE & \\
\hline \multirow{5}{*}{$\begin{array}{l}\text { Martinez- } \\
\text { Aguilar }{ }^{3}\end{array}$} & 2004 & 59 & 5 & $\mathrm{U}$ & $\mathrm{U}$ & Osteo. & Unkown & MRSA & Unkown & Unknown & PVL \\
\hline & & & & $\mathrm{U}$ & $\mathrm{U}$ & Osteo. & Unkown & MRSA & Unkown & Unknown & PVL \\
\hline & & & & $\mathrm{U}$ & $\mathrm{U}$ & Osteo. & Unkown & MRSA & Unkown & Unknown & PVL \\
\hline & & & & $\mathrm{U}$ & $\mathrm{U}$ & Osteo. & Unkown & MRSA & Unkown & Unknown & PVL \\
\hline & & & & $\mathrm{U}$ & $\mathrm{U}$ & Osteo. & Unkown & MSSA & Unkown & Unknown & PVL \\
\hline Yuksel $^{4}$ & 2004 & & 1 & 3 & $\mathrm{~m}$ & Osteo. & $\begin{array}{l}\text { R distal } \\
\text { fibula }\end{array}$ & S aureus & R external iliac & $\begin{array}{l}\text { Bil. Densities; } \\
\text { cavities }\end{array}$ & \\
\hline \multirow[t]{9}{*}{ Gonzalez $^{6}$} & 2006 & 116 & 9 & 12 & $\mathrm{~m}$ & Osteo. & R ilium & MSSA & $\mathrm{R}$ deep pelvic & Clear & \\
\hline & & & & 3 & $\mathrm{~m}$ & Osteo. & $R$ femur & MRSA & $\begin{array}{l}\text { R common femoral; } \\
\text { external iliac }\end{array}$ & Clear & PVL \\
\hline & & & & 3 & $\mathrm{~m}$ & Osteo. & R tibia & MSSA & $\mathrm{R}$ femoral; popliteal & Clear & \\
\hline & & & & 10 & $\mathrm{~m}$ & Osteo. & $\begin{array}{l}\text { L ischium, } \\
\text { pubis } \\
\text { \& ilium }\end{array}$ & MRSA & L common iliac & Bilateral infiltrates & PVL; CVC \\
\hline & & & & 14 & $\mathrm{~m}$ & Osteo. & $\begin{array}{l}\mathrm{R} \text { femur } \\
\text { and tibia }\end{array}$ & MRSA & $\mathrm{R}$ femoral; popliteal & SPE & PVL; CVC \\
\hline & & & & 13 & $\mathrm{~m}$ & Osteo. & $\begin{array}{l}\text { L femur } \\
\text { and tibia }\end{array}$ & MRSA & L saphenous & Pleural effusions & PVL; CVC \\
\hline & & & & 14 & $\mathrm{~m}$ & Osteo. & L tibia & MRSA & L popliteal; saphenous & SPE & PVL \\
\hline & & & & 11 & $\mathrm{~m}$ & Osteo. & L femur & MRSA & L femoral vein & SPE & PVL; CVC \\
\hline & & & & 14 & $\mathrm{~m}$ & Osteo. & $\mathrm{R}$ femur & MRSA & $\begin{array}{l}\text { R common femoral; } \\
\text { popliteal }\end{array}$ & SPE & PVL; CVC \\
\hline \multirow[t]{8}{*}{$\begin{array}{l}\text { Crary }^{5} ; \\
\text { Hollmig }\end{array}$} & $2006 / 7$ & 352 & 15 & 13 & $\mathrm{~m}$ & Osteo. & $\begin{array}{l}\mathrm{R} \text { distal } \\
\text { femur }\end{array}$ & MRSA & SVC & Clear & CVC \\
\hline & & & & 13 & $\mathrm{~m}$ & Osteo. & $\begin{array}{l}\text { R proximal } \\
\text { fibula }\end{array}$ & MRSA & R femoral; popliteal & Clear & CVC \\
\hline & & & & 9 & $\mathrm{~m}$ & Osteo. & $\begin{array}{l}\text { R proximal } \\
\text { tibia }\end{array}$ & MRSA & R femoral; popliteal & SPE & CVC \\
\hline & & & & 11 & $\mathrm{f}$ & Osteo. & $\begin{array}{l}\text { L distal } \\
\text { femur }\end{array}$ & MRSA & L femoral; popliteal & SPE & CVC \\
\hline & & & & 12 & $\mathrm{~m}$ & Osteo. & $\begin{array}{l}\text { R proximal } \\
\text { tibia }\end{array}$ & MRSA & \multicolumn{2}{|c|}{$\begin{array}{l}\text { SVC; L internal jugular; Clear } \\
\text { subclavian }\end{array}$} & CVC \\
\hline & & & & 10 & $\mathrm{f}$ & Osteo. & L sacrum & MRSA & $\begin{array}{l}\text { L common iliac; L } \\
\text { external iliac }\end{array}$ & $\begin{array}{l}\text { Bil. opacities; } \\
\text { effusions }\end{array}$ & CVC \\
\hline & & & & 13 & $\mathrm{~m}$ & Osteo. & $\begin{array}{l}\text { R distal } \\
\text { femur }\end{array}$ & MSSA & R femoral; popliteal & Unknown & CVC \\
\hline & & & & 7 & $\mathrm{~m}$ & Osteo. & $\begin{array}{l}\text { Thoracic } \\
\text { spine }\end{array}$ & MRSA & Azygous; IVC & SPE & CVC \\
\hline
\end{tabular}




\begin{tabular}{|c|c|c|c|c|c|c|c|c|c|c|c|}
\hline Source & Year & Series & DVT & Age $(y)$ & Sex & Type & Location & Organism & DVT Site & $\begin{array}{l}\text { Pulmonary } \\
\text { Findings }\end{array}$ & Features \\
\hline & & & & 10 & $\mathrm{~m}$ & Osteo. & $\begin{array}{l}\text { R proximal } \\
\text { femur }\end{array}$ & MRSA & R femoral & $\overline{\mathrm{SPE}}$ & CVC \\
\hline & & & & 2 & $\mathrm{~m}$ & Osteo. & $\begin{array}{l}\text { R proximal } \\
\text { tibia }\end{array}$ & MRSA & $\begin{array}{l}\mathrm{R} \text { femoral; external } \\
\text { iliac; saphenous }\end{array}$ & SPE & CVC \\
\hline & & & & 14 & $\mathrm{~m}$ & Osteo. & $\begin{array}{l}\text { L distal } \\
\text { femur }\end{array}$ & MSSA & L popliteal & SPE & CVC \\
\hline & & & & 4 & $\mathrm{~m}$ & Osteo. & $\begin{array}{l}\text { L proximal } \\
\text { tibia }\end{array}$ & \multicolumn{2}{|c|}{ C. Tropicalis L popliteal } & Unknown & CVC \\
\hline & & & & 6 & $\mathrm{f}$ & Osteo. & \multicolumn{2}{|c|}{$\begin{array}{l}\text { L distal tibia, MRSA } \\
\text { L distal } \\
\text { femur }\end{array}$} & IVC and SVC & Unknown & CVC \\
\hline & & & & 8 & $\mathrm{f}$ & Pyom. & L calf & \multicolumn{2}{|c|}{ Strep. MilleriL posterior tibial } & \multicolumn{2}{|l|}{ Clear } \\
\hline & & & & 6 & $\mathrm{f}$ & $\begin{array}{l}\text { Sep. } \\
\text { Art. }\end{array}$ & L hip & GABHS & $\begin{array}{l}\text { R IJ; Sigmoid; } \\
\text { transverse sinues }\end{array}$ & Clear & \\
\hline Castaldo $^{7}$ & 2007 & & 1 & $\mathrm{U}$ & $\mathrm{U}$ & $\begin{array}{l}\text { Sep. } \\
\text { Art. }\end{array}$ & Hip & MRSA & Unkown & $\begin{array}{l}\text { Necrotizing } \\
\text { pneumonia }\end{array}$ & \\
\hline \multirow[t]{3}{*}{ Dohin $^{8}$} & \multirow[t]{3}{*}{2007} & \multirow[t]{3}{*}{39} & \multirow[t]{3}{*}{3} & $\mathrm{U}$ & $\mathrm{U}$ & $\mathrm{U}$ & Unknown & $\mathrm{S}$ aureus & Unkown & Unknown & PVL \\
\hline & & & & $\mathrm{U}$ & $\mathrm{U}$ & $\mathrm{U}$ & Unknown & S aureus & Unkown & Unknown & PVL \\
\hline & & & & $\mathrm{U}$ & $\mathrm{U}$ & $\mathrm{U}$ & Unknown & $S$ aureus & Unkown & Unknown & PVL \\
\hline \multirow[t]{3}{*}{ Mitchell10 } & \multirow[t]{3}{*}{2007} & & \multirow[t]{3}{*}{3} & 9 & $\mathrm{~m}$ & Osteo. & $\begin{array}{l}\text { R proximal } \\
\text { femur }\end{array}$ & MSSA & $\begin{array}{l}\text { L femoral; bilateral IJs; } \\
\text { R brachial }\end{array}$ & Unknown & ICU; PVL \\
\hline & & & & 9 & $\mathrm{~m}$ & Osteo. & $\begin{array}{l}\text { R proximal } \\
\text { femur }\end{array}$ & S aureus & R femoral & \multicolumn{2}{|c|}{ Bilateral infiltrates ICU; PVL } \\
\hline & & & & 13 & $\mathrm{~m}$ & Osteo. & $\begin{array}{l}\mathrm{R} \text { femur } \\
\text { and tibia }\end{array}$ & S aureus & Unkown & SPE & PVL \\
\hline \multirow[t]{2}{*}{ Nourse $^{11}$} & \multirow[t]{2}{*}{2007} & & \multirow[t]{2}{*}{2} & 1 & $\mathrm{~m}$ & Osteo. & L femur & MRSA & $\begin{array}{l}\text { L superficial/common } \\
\text { femoral; iliac }\end{array}$ & SPE & PVL \\
\hline & & & & 13 & $\mathrm{~m}$ & Osteo. & $\begin{array}{l}\text { L proximal } \\
\text { femur }\end{array}$ & MRSA & $\begin{array}{l}\text { L superficial/common } \\
\text { femoral }\end{array}$ & SPE & PVL \\
\hline \multirow[t]{3}{*}{ Gite $^{12}$} & \multirow[t]{3}{*}{2008} & & \multirow[t]{3}{*}{3} & 8 & $\mathrm{U}$ & Osteo. & $\mathrm{R}$ femur & No growth & Unkown & \multirow{2}{*}{\multicolumn{2}{|c|}{$\begin{array}{l}\text { Unknown } \\
\text { Unknown }\end{array}$}} \\
\hline & & & & 6 & $\mathrm{U}$ & Osteo. & L femur & Enterococcus & Unkown & & \\
\hline & & & & 13 & $\mathrm{U}$ & Osteo. & L femur & $\mathrm{S}$ aureus & Unkown & Unknown & \\
\hline McDonald ${ }^{13}$ & 2010 & & 1 & 5 & $\mathrm{~m}$ & Osteo. & $\begin{array}{l}\text { R proximal } \\
\text { humerus }\end{array}$ & MRSA & $\begin{array}{l}\text { R subclavian; brachial; } \\
\text { cephalic }\end{array}$ & SPE & ICU \\
\hline
\end{tabular}

DVT-Deep vein thrombosis; y-years; m-Male; f-Female; U-Unknown; Osteo.-Osteomyelitis; R-Right; LLeft; MSSA-Methicillin Senstive Staph Aureus; Bil.-Bilateral;

MRSA-Methicillin Resistant Staph Aureus; S-staphyloccocus; GABHS-Group A beta hemolytic streptoccocci; IVC-Inferior vena cava; SVC-Superior vena cava;

SPE-Septic pulmonary emboli; PneumoT-Pneumothorax; ICU-Intensive care unit; Comp. sy.-

Compartment syndrome; PVL-Panton-Valentine Leukocidin; C. Candida;

CVC-Central venous catheters; Sep. Art.- Septic Arthritis; Strep.- Streptoccocus; IJ-Internal jugular

Table 1. Summary of Published Cases of DVT in Patients with Musculoskeletal Infection

(73.9\%).1-19 The average age of the children with DVT in the reviewed studies was 9 years with only six children under the age of 4 years among the 49 children with a recorded age $(12.2 \%) .{ }^{1-}$ 19 The type of infection was found to be osteomyelitis in 51 out of the 55 cases $(92.7 \%)$ in which the musculoskeletal infection type was delineated. 1-19 However, two cases of septic arthritis and two cases of pyomyositis were also noted., 2,,9 The location of the infection was reported in 46 out of the 54 children with osteomyelitis and noted to be unifocal in 40 children and multifocal in the remaining six (see table 2). The site of osteomyelitis was most commonly reported in the femur (26 occurrences), and specifically reported in the proximal femur on 7 occasions and the distal femur on 6 occasions. The tibia was the second most common location of osteomyelitis (13 occurrences) with the proximal tibia specified in 5 cases and the distal tibia specified in one case. Overall, the location of the musculoskeletal infection was found to be in the pelvis (ilium, ischium, pubis, or sacrum) or lower extremities in 48 out of the 51 cases in which the site of infection was reported $(94.1 \%)$, with the three remaining cases identified in the upper extremities (humerus in two children) and thoracic spine. 


\begin{tabular}{llcc} 
Location & & Recorded occurrence & Percent \\
\hline Thoracic spine & & 1 & $2 \%$ \\
\hline Pelvis & Ilium & 5 & \\
& Ischium & 1 & $9 \%$ \\
& Pubis & 1 & $2 \%$ \\
& Sacrum & 3 & $2 \%$ \\
& Total & 10 & $6 \%$ \\
\hline Femur & Unspecified & 13 & $25 \%$ \\
& Proximal & 7 & $13 \%$ \\
& Distal & 6 & $11 \%$ \\
& Total & 26 & \\
\hline Tibia & Unspecified & 7 & $13 \%$ \\
& Proximal & 5 & $9 \%$ \\
& Distal & 1 & $2 \%$ \\
& Total & 13 & \\
\hline Fibula & & & $2 \%$ \\
& Proximal & 1 & $4 \%$ \\
& Distal & 2 & $100 \%$ \\
\hline Total & Total & 3 & $12 \%$ \\
\hline Multifocal & & 53 & \\
\hline
\end{tabular}

Table 2. Frequency Distribution of Osteomyelitis Site

\section{Causative organism}

Staphylococcus aureus was found to be the causative organism in 38 of 43 culture positive cases $(88.4 \%)$ and, of those isolates, $18(47.4 \%)$ were identified as Methicillin-resistant Staphylococcus aureus. In one series, the rise in recognition of DVT in their practice appeared to coincide with the establishment of USA 300 ST8 as the predominant clone of CA-MRSA in their community. ${ }^{6}$

\section{Panton-Valentine leukocidin}

The identification of Panton-Valentine leukocidin (PVL) genes in the isolates of Staphylococcus aureus in children with DVT has been reported in several studies.3,6,8,10,11 These reports suggest that PVL may be associated with enhanced inflammatory response in cases of musculoskeletal infection including pneumonia, multifocal osteomyelitis, bacteremia, and concurrent pyomyositis, subperiosteal abscesses or intra-osseous abscesses requiring surgical debridment.3,6,8,10,11 The advent of rapid PCR technology as a tool to identify the presence of PVL may prove valuable in identifying potentially "silent" cases of DVT that would otherwise go unrecognized. To this point, however, the technology to perform rapid testing to identify the bacterial genetics of the $S$. aureus isolates is not readily available at most institutions. Our meta-analysis identified 20 children out of the 58 reported cases with DVT who were found to be PVL positive (34.5\%).3,6,8,10,11 


\section{Location of DVT}

Among the 58 children with DVT, the location of occurrence of the DVT was recorded in 45 cases and was noted to be multi-focal in $22(48.9 \%)$ children (see table 3). 79 specific locations of the DVT were recorded with the most common being femoral (25 or 32\%); popliteal (14 or $18 \%)$; iliac (12 or $15 \%)$; and inferior vena cava (6 or $8 \%$ ). Overall, the reported incidence of DVT involving a location inclusive of the inferior vena cava, pelvis, or lower extremities was 62 of the 79 occurrences $(78.5 \%)$.

\begin{tabular}{lrr} 
Location of DVT & Occurrence & \\
\hline Sigmoid Sinus & 1 & $1 \%$ \\
Transverse Sinus & 1 & $1 \%$ \\
Internal Jugular & 4 & $5 \%$ \\
Superior Vena Cava & 3 & $4 \%$ \\
Subclavian & 2 & $3 \%$ \\
Arm & 4 & $5 \%$ \\
Atrium & 1 & $1 \%$ \\
Azygous & 1 & $1 \%$ \\
Inferior Vena Cava & 6 & $8 \%$ \\
Iliac & 12 & $15 \%$ \\
Femoral & 25 & $32 \%$ \\
Popliteal & 14 & $18 \%$ \\
Posterior Tibial & 1 & $1 \%$ \\
Peroneal & 1 & $1 \%$ \\
Saphenous & 3 & $4 \%$ \\
\hline Total & 79 & $100 \%$ \\
\hline Multiple locations reported & 22 & \\
\hline Location not reported & 13 &
\end{tabular}

Table 3. Frequency Distribution of DVT Location

\section{Clinical features}

Several studies have suggested that children with DVT- associated osteomyelitis demonstrate a more severe clinical course when compared to children who do not have deep venous thrombosis.3,5,6,8,9,10,11 Specifically, children with DVT are more likely to be admitted to the intensive care unit (ICU), require more surgical procedures, and have a longer hospitalization than their counterparts who do not have DVT but who do have similar forms of musculoskeletal infection. 2,5,9,10,13,17,19 One study found that children with DVT required an average of 2.6 surgical procedures per child and had a mean duration of hospitalization of 30.6 days, compared to children without DVT who underwent an average of 0.9 surgical procedures per child and were hospitalized an average of 9.5 days. ${ }^{9}$ The same study determined that children with DVT presented with higher inflammatory indices in comparison to children who did not have DVT. ${ }^{9}$ The mean C-reactive protein (CRP) in children with DVT was $16.9 \mathrm{mg} / \mathrm{dL}$, compared with only $6.8 \mathrm{mg} / \mathrm{dL}$ in children without DVT. 9 While intuitively it might be thought that children with DVT would have a delay in clinical presentation to a healthcare facility, the authors found that there was in fact a 
shorter duration between the onset of admission for children with DVT compared to those without. (5.6 days versus 14.4 days). ${ }^{9}$ This lends further support to the possibility that children with musculoskeletal infection and DVT have a more abrupt onset and rapid clinical decline to the point where medical attention is sought. Pulmonary involvement with a variety of manifestations including pneumonia, septic pulmonary emboli, cavitary pneumatoceles, empyema, and various infiltrates was recorded in 36 of the 58 children with DVT (62.1\%).1,2,4-7,9-11,13-19

\section{Central venous catheters}

The use of central venous catheters (CVCs) in the treatment of children with musculoskeletal infection has raised the concern that these catheters may be associated with risk including DVT development. Our review noted the concurrent presence of CVLs in several children with DVT, but the conclusions were generally that there was no clear relationship. $5,6,9$ Hollmig et al. found that CVCs were used in all eleven children with osteomyelitis and DVT in their series. ${ }^{9}$ However, there did not appear to be a relationship between the location or temporal onset of the DVT to the CVC in their experience. ${ }^{9}$

\section{Statistical analysis}

We reviewed 19 articles (15 case reports 1,2,4,5,710-19, three studies pertaining to musculoskeletal infection in general $3,8,9$, and one study focused on an osteomyelitis population 6 ). In estimating the heterogeneity of the three musculoskeletal infection papers $(\mathrm{k}=3)$, we measured the $\mathrm{I}^{2}$ index as our test of heterogeneity and found the $\mathrm{I}^{2}$ index to be $7.7 \%$. The Cochran's $\mathrm{Q}$ value was found to be $2.153(\mathrm{p}=0.3407)$. This statistic signifies a degree of heterogeneity between the three papers which makes it difficult to derive meaningful conclusions from the summary data from these studies. However, this level of heterogeneity is expected considering several factors such as different study methodology, different timing of the onset of disease, different disease severity and different patient groups.

The incidence rate of DVT was calculated to compare the difference between an incidence rate specific to osteomyelitis and the incidence related to musculoskeletal infection in general. From our results, the number of DVTs in the three musculoskeletal infection papers was 23 with a sample size of $450.3,8,9$ Therefore the incidence of DVT in children with musculoskeletal infection was 5.1\%. However, in the one paper in which osteomyelitis alone was considered, the number of DVTs was 9 with a sample size of $116 .{ }^{6}$ Hence, the incidence of DVT with osteomyelitis was $7.8 \%$. Although the differences in incidence could be due to different populations being studied, there does appear to be a higher incidence of DVT specifically with pediatric osteomyelitis as compared to pediatric musculoskeletal infection in general. Further research is required in this area.

\section{Evaluation recommendations}

Any child with deep musculoskeletal infection, particularly osteomyelitis caused by Staphylococcus aureus should be considered at risk for DVT. However, in light of the medical literature, a higher index of suspicion should be held for those children with severe clinical presentation, including: intensive care unit admission, markedly elevated inflammatory indices, lower extremity location of the musculoskeletal infection, need for repeated surgical debridement, and pulmonary involvement with infiltrates or septic pulmonary emboli. These 
children should undergo screening with non-invasive Doppler ultrasound evaluation of the extremities in the region of the musculoskeletal infection to look for DVT. If the ability to assess the PVL status of the organism is present within any institution, then this should be considered whenever Staphylococcus aureus is isolated from bone, joint, or muscle specimens.

While stratification of the relative risk of DVT may increase the awareness of the treating physician of the child's potential for DVT, it is important not to overlook the rare cases of DVT that might occur in children who fall outside of this risk profile, such as those with upper extremity locations of infection, infection types other than osteomyelitis, causative organisms other than Staphylococcus aureus, or age under 4 years. Whenever the clinical suspicion of DVT exists, supplemental imaging should be considered.

\section{Treatment}

Children with DVT and osteomyelitis can be effectively managed with low molecular weight heparin. Resolution of the DVT occurs at an average of ten to twelve weeks.5,9 Follow-up imaging is helpful to ensure resolution of the DVT. In cases refractory to low molecular-weight heparin, consideration may be given to placement of an intravascular filter. Warfarin is also an option, but requires additional effort in managing the prothrombin time (PT) and international normalized ratio (INR) effectively.

Because children with DVT and osteomyelitis may require repeat surgical procedures, care must be taken to appropriately withhold and resume the anticoagulant therapy around periods of surgery to avoid bleeding complications.

\section{Conclusions}

Pediatric musculoskleletal infection is associated with the risk for DVT. Risk factors include: osteomyelitis; lower extremity location of infection; Staphylococcus aureus, particularly MRSA, as the causative organism; age greater than 4 years; markedly elevated inflammatory indices; severe clinical illness often requiring intensive care unit admission, intubation, or inotrope support; and pulmonary involvement with infiltrates, pneumonia, or septic pulmonary emboli. A high index of suspicion should be maintained when risk factors are present and appropriate screening imaging should be obtained. One study demonstrated a $40 \%$ rate of DVT when the child was greater than 8 years of age with positive cultures for MRSA and an initial CRP of greater than $6 \mathrm{mg} / \mathrm{dL} .{ }^{9}$ Consideration may be given to evaluating for the presence of PVL within the bacterial genetics to help further stratify the risk of DVT. Whenever DVT is identified, appropriate treatment should be administered in a timely manner and the child should be monitored until the point of resolution. The anticipated outcome is good.

\section{References}

[1] Newgard C. D, Inkelis S. H, \& Mink R. (2002). Septic thromboembolism from unrecognized deep venous thrombosis in a child. Pediatric Emergency Care, 18(3), 192-196.

[2] Walsh Stewart, \& Philips Fredrick. (2002). Deep vein thrombosis associated withpediatric musculoskeletal sepsis. Journal of Pediatrics Orthopedics, 22, 329-332.

[3] Martinez-Aguilar G, Avalos-Mishaan A, Hulten K, Hammerman W, Mason E O, \& Kaplan S L. (2004). Community acquired methicillin-resistant and methicillin- 
susceptible staphylococcus aureus musculoskeletal infections in children. The Pediatric Infectious Disease Journal, 23, 701-706.

[4] Yuksel Hasan, Ozguven Ali Aykan, Akil Ipek, Erguder Isil, Yilmaz Dilek, \& Cabuk Mine. (2004). Septic pulmonary emboli presenting with deep venous thrombosis secondary to acute osteomyelitis. Pediatrics International, 46, 621-623.

[5] Crary S E, Buchanan G R, Drake C E, \& Journeycake J M. (2006). Venous thrombosis and thromboembolism in children with osteomyelitis. The Journal of Pediatrics, 149, 537-541.

[6] Gonzalez B E, Teruya J, Mahoney D H, Hulten K G, Edwards R, Lamberth L B, et al. (2006). Venous thrombosis associated with staphylococcal osteomyelitis in children. Pediatrics, 117, 1673-1679.

[7] Castaldo ET, \& EY, Y. (2007). Severe sepsis attributable to community-acquired methicillin-resistant staphylococcus aureus: an emerging fatal problem. The American Surgeon, 73, 684-687.

[8] Dohin B, Gillet Y, Kohler R, Lina G, Vandenesch F, Vanhems P, et al. (2007). Pediatric bone and joint infections caused by panton-valentine leukocidin-positive staphlococcus aureus. Pediatric Infectious Disease, 26, 1042-1048.

[9] Hollmig S T, Copley L A, Browne R H, Grande L M, \& Wilson P L. (2007). Deep venous thrombosis associated with osteomyelitis in children. Journal of Bone and Joint Surgery, 89, 1517-1523.

[10] Mitchell PD, Hunt DM, Lyall H, Nolan M, \& Tudor-Williams G. (2007). Panton-valentine leukocidin-secreting staphylococcus aureus causing severe musculoskeletal sepsis in children. A new threat. Journal of Bone and Joint Surgery, 89-B(No. 9), 1239-1242.

[11] Nourse C, Starr M, \& W, M. (2007). Community-acquired methicillin-resistant staphylococcus aureus causes severe disseminated infection and deep venous thrombosis in children: literature review and recommendations for management. Journal of Pediatric Child Health, 43, 656-661.

[12] Gite A, Trived R, \& Ali U. S. (2008). Deep Vein Thrombosis Associated with Osteomyelitis. Indian Pediatrics, 45, 418-419.

[13] McDonald John E, \& A, C. L. (2010). Upper extremity deep venous thrombosis associated with proximal humeral osteomyelitis in a child. The Journal of Bone and Joint Surgery, America, 92, 2121-2124.

[14] Horvath F. L, Brodeur A. E, \& Cherry J. D. (1971). Deep thrombophlebitis associated with acute osteomyelitis. Journal of Pediatric, 79(5), 815-818.

[15] Jupiter J. B, Ehrlich M. G, Novelline R. A, Leeds H. C, \& Keim D. (1982). The association of septic thrombophlebitis with subperiosteal abscesses in children. Journal of Pediatric, 101(5), 690-695.

[16] von Muhlendahl KE. (1988) Pelvic and femoral vein thrombosis in childhood [in German]. Monatsschr Kinderheilkd, 136: 397-399.

[17] Smith A. G, Cornblath W. T, \& Deveikis J. P. (1997). Local thrombolytic therapy in deep cerebral venous thrombosis. Neurology, 48(6), 1613-1619.

[18] Letts Merv, Lalonde Francois, Davidson Darin, Hosking Martin, \& Halton Jacqueline. (1999). Atrial and venous thrombosis secondary to septic arthritis of the sacroiliac joint in a child with hereditary protein c deficiency. Journal of Pediatrics Orthopedics, 19(2)(March/April 1999), 156-160.

[19] Gorenstein Arkadi, Gross Eitan, Houri Sion, Gewirts Gabriella, \& Katz Schmuel. (2000). The pivotal role in deep vein thrombophlebitis in the development of acute disseminated staphylococcal disease in children. Pediatrics, 106(No. 6), 87-89. 


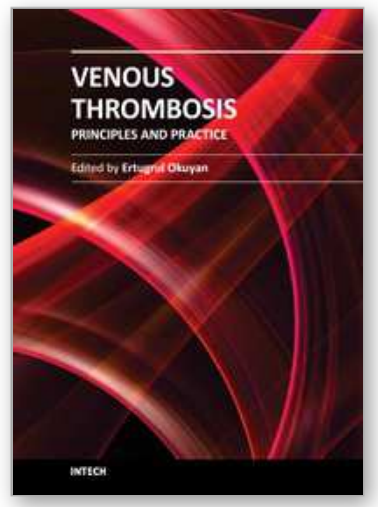

\author{
Venous Thrombosis - Principles and Practice \\ Edited by Dr. Ertugrul Okuyan
}

ISBN 978-953-307-885-4

Hard cover, 232 pages

Publisher InTech

Published online 05, January, 2012

Published in print edition January, 2012

According to Virchow's triad, venous thrombosis can occur as a result of one or more of three factors: changes in the dynamics of the blood flow, endothelial injury/dysfunction of the blood vessel and hypercoagulability. The blood in the veins is constantly forming microscopic thrombi that are routinely broken down by the body, and significant clotting can occur only when the balance of thrombus formation and resolution is altered. This book is a fresh synthesis of venous thromboembolism care and considers the opinions and studies from different fields of medicine. As venous thrombosis spectrum is wide and can affect many organ systems, from deep veins of the leg to the cerebral venous system, our intent is for this to be a comprehensive, up-to-date and readable book. We tried to present a synthesis of existing material infused with new ideas and perspectives and authors own clinical studies and even case-reports.

\title{
How to reference
}

In order to correctly reference this scholarly work, feel free to copy and paste the following:

Lawson A. B. Copley and Ngozi Okoro (2012). Deep Venous Thrombosis in Children with Musculoskeletal Infection, Venous Thrombosis - Principles and Practice, Dr. Ertugrul Okuyan (Ed.), ISBN: 978-953-307-885-4, InTech, Available from: http://www.intechopen.com/books/venous-thrombosis-principles-and-practice/deepvenous-thrombosis-in-children-with-musculoskeletal-infection

\section{INTECH}

open science | open minds

\author{
InTech Europe \\ University Campus STeP Ri \\ Slavka Krautzeka 83/A \\ 51000 Rijeka, Croatia \\ Phone: +385 (51) 770447 \\ Fax: +385 (51) 686166 \\ www.intechopen.com
}

\author{
InTech China \\ Unit 405, Office Block, Hotel Equatorial Shanghai \\ No.65, Yan An Road (West), Shanghai, 200040, China \\ 中国上海市延安西路65号上海国际贵都大饭店办公楼 405 单元 \\ Phone: +86-21-62489820 \\ Fax: +86-21-62489821
}


(C) 2012 The Author(s). Licensee IntechOpen. This is an open access article distributed under the terms of the Creative Commons Attribution 3.0 License, which permits unrestricted use, distribution, and reproduction in any medium, provided the original work is properly cited. 